\title{
93 耳鳴の重症度に影響を与える因子
}

○高橋真理子、蒲谷嘉代子、田中史子、荒木幸絵、村上信五 名古屋市立大学

耳鳴の感じ方は個人差があり、耳鳴がしているという状態だけで重症度を判断することは難しい。われわれは、耳鳴苦痛 度の評価には Tinnitus Handicap Inventory（以下 THI）などの質問紙票を用いている。THI は耳鳴に関係する25項目の質問 項目から成り立っており、合計100点満点で計算し、その点数により重症度分類が可能である。

今回、その耳鳴の重症度に影響を与える因子について、名古屋市立大学耳鼻咽喉科 耳鳴外来を受診した186名（男性89 名、女性97名）について、年齢、聴力、ピッチマッチ、ラウドネスバランス、抑うつ、不安などの因子について検討したた め報告する。

\section{4 一般耳鼻科臨床の場で実践できる慢性耳鳴の対応}

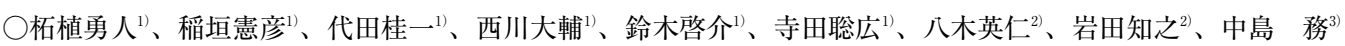
名古屋第一赤十字病院 耳鼻咽喉科 ${ }^{12}$ 、稲沢市民病院 耳鼻咽喉科 ${ }^{2}$ 、名古屋大学 医学部 耳鼻咽喉科 ${ }^{3}$

耳鳴患者への対応は時間を要することもあり、診療の現場ではお座なりであることも多い。その理由の一つは、「耳鳴は 治らない」と医師自身が考えているからと思う。筆者も以前はそうであったが、耳鳴再訓練療法 (Tinnitus Retraining Therapy：TRT）の治療に関わって以来、「耳鳴の音」は消えなくても「耳鳴の苦痛」を取ることが出来ることを多くの患者より 学んだ。そのため、TRTを懐疑的にみる意見に対して、TRTの本質を伝えたい思いを覚える。しかしながら、TRTの究極 の目標である「脳の可塑性が耳鳴音を減少させる」ことを実感できる機会は限られており、苦痛の軽減が現実的な目標であ ることは認めざるをえない。とは言え、TRTを中心とした対応で耳鳴の苦痛から救われる患者は多いわけで、TRTの考え 方を一般臨床に取り入れれば軽症の耳鳴患者の対応は専門外来でなくても可能である。

今回の発表では、TRT の本質を伝えられるように努めて、一般耳鼻科臨床の場で実践できる自然環境音や補聴器による 音響療法を中心にまとめて提案する。

\section{5 難治性耳鳴症の臨床的特徵と治療について}

○石井正則 ${ }^{1)} 、$ 茂木雅臣1)、元山智恵 ${ }^{1} 、$ 佐伯亜希子 ${ }^{1)}$ 、近沢仁志 ${ }^{2}$

東京厚生年金病院 耳鼻咽喉科12、東京慈恵会医科大学 耳鼻咽喉科 ${ }^{2}$

【目的】難治性の耳鳴症に対して臨床的特徴を解析し、治療について明らかにする。【方法】2007年 1月～2011年 6 月まで の期間で、耳鳴りを主訴とした患者で東京厚生年金病院を受診した患者46名を対象とした。39歳〜81歳、平均年齢61. 8歳で 男女比は 1：1.6と女性に多い傾向を示した。片側性が約 8 割であり、残りの 2 割は両側性で、いわゆる頭鳴りを訴えてい た。全例に純音聴力検査だけではなく、不安とストレスの指標として STAI 検査を行い、さらに自律神経問診票、SRQ-D 検查、SDS 検查、ピッツバーグ睡眠問診票を用いた。【成績】全例に感音難聴を認め、多くの症例に多彩な自律神経症状を 呈していた。うつ病は 5 名いて、心療内科との連携で治療した。高度の睡眠障害とストレスや不安を訴える症例に対して は、抗不安薬と睡眠導入剂を用い、綿密な生活指導を行い、良好な成績を治めた。結論】難治性の耳鳴症には、患者の背 景因子を十分考慮する必要がある。その把握のために上記のような詳細な検査で患者個人の状況を理解し、それに応じた治 療法を用いることが大切である。

\section{6 needle tract implantation 後未分化転化を起こした甲状腺乳頭癌再発リンパ節の 1 例}

○友田智哲、坂部亜希子、榎本友美子

東京労災病院 耳鼻咽喉科

エコーガイド下細胞診（FNAB）は甲状腺腫瘍の診断ツールとして重要なものの一つである。合併症として、血腫、甲状 腺浮腫、 needle tract implantation ( $0.14 \%$ 程度) などがあげられる。今回われわれは、甲状腺乳頭癌初回手術後リンパ節再 発を来し、その後同部位の needle tract implantation および未分化転化を来した症例を経験したので報告する。

症例は76歳女性。甲状腺右葉 $(1.6 \mathrm{~cm})$ 㧍よび両頸部リンパ節転移に対して、甲状腺全摘、両側保存的頸部郭清術施行。 病理組織は甲状腺高細胞型乳頭癌。初回手術 2 年後に左 $\mathrm{Vb}$ リンパ節出現 $(1.5 \mathrm{~cm} 、 \mathrm{FNAB}$ ： class $\mathrm{V} 、 \mathrm{Tg}$ 穿刺液 $>8,000)$ 。 そのまま経過観察するも、 5 年後 needle tract implantation と肺転移が出現し、リンパ節も $3.1 \mathrm{~cm}$ まで増大した。再度細胞 診を施行。未分化癌（Tg 穿刺液：165）と診断。頸部リンパ節摘出と術後タキソールによる補助療法を施行した。現在担癌 生存中である。 
97 甲状腺乳頭癌が頸部リンパ節転移巣で未分化転化したと判断した 3 症例

○古川竜也、岩江信法、平山裕次、手島直則、松居秀敏

兵庫県立がんセンター 頭頸部外科

【背景】甲状腺未分化癌は極めて予後不良の疾患である。未分化転化に至る機序は不明な部分が多いが、高分化癌のリン パ節転移巣や遠隔転移巣からも発生することが知られている。今回われわれは乳頭癌の転移リンパ節から未分化癌が発生し たと考えられる 3 症例を経験したので報告する。【症例 $1 、 2 】$ 上頸部腫瘤を主訴に受診した。唾液腺癌の診断で手術を施 行し術後組織診断で甲状腺未分化癌と判明した。いずれの症例も甲状腺に結節性病変を認めるが術後も増大はなく、腺内病 変は未分化癌ではないと判断した。症例 1 は無再発生存中であるが、症例 2 は内頸静脈内腫瘍塞栓のため非治癒切除となり 死亡した。【症例 $3 】$ 甲状腺乳頭癌で甲状腺全摘出術後の経過観察中、頸部に小腫瘤が出現し 1 力月の間に急速に増大し た。乳頭癌の転移と考え急ぎ頸部郭清を施行したが、治癒切除不能に終わり死亡した。転移部の術後組織診断は未分化癌で あった。【まと】転移巣のみが未分化転化している甲状腺高分化癌症例が存在することを念頭に置いて検査治療にあたる 必要性があると思われた。

\section{8 集学的治療を行った甲状腺びまん性硬化型乳頭癌}

○荒木真美佳、杉山智宣、福喜多晃平、谷山岳司、山田弘之 伊勢赤十字病院 耳鼻咽喉科

「はじめに」甲状腺びまん性硬化型乳頭癌は、乳頭癌の特殊型に分類されるまれな疾患であり、腫瘍は結節性病変を形成 せず、早期から広範なリンパ節転移を来すのが特徵である。「症例」30歳女性。頸部の違和感を主訴に近医受診した。初診 時、甲状腺は右葉を中心に甲状腺の腫大を認め、頸部リンパ節の腫脹も認めた。エコー上は甲状腺内に腫瘤形成を認めなか ったが、内部に微細石灰化を認め、穿刺吸引細胞診で乳頭癌と診断された。甲状腺びまん型硬化型乳頭癌と診断し、甲状腺 全摘と両 D2a 郭清術を施行した。周囲への浸潤はなかったが、著明なリンパ節転移があり、病期は pT3N1bM0 であった。 術後、他院で放射性ヨード内用療法を施行し、現在は再発や転移なく経過している。「まとめ」甲状腺びまん性硬化型乳頭 癌は、臨床的に良性甲状腺腫や橋本病を思わせる所見を示すことが多く、診断が困難な例が見られるが、確実に診断し治癒 切除を行えば予後良好な疾患であるといえる。

\section{9 甲状腺乳頭癌の胸骨転移に対して胸骨切除術を施行した 1 例}

○宮村朋孝、荻原仁美、石永一、竹内万彦

三重大学 大学院 医学系研究科 耳鼻咽喉・頭頸部外科

甲状腺乳頭癌の骨転移は1.4〜 7\%に存在しその中では胸骨転移はまれではないが、治療法は確立されていない。今回、 われわれは甲状腺乳頭癌胸骨転移に対し胸骨切除術を施行したので報告する。症例は66歳女性、8 年前に甲状腺癌にて左葉 切除＋左頸部郭清術を施行後、右頸部リンパ節に転移あり残葉切除＋右頸部郭清術を施行された。経過観察中、PET-CTに て喉頭部に集積あり、甲状軟骨へ浸潤する腫瘍を認め、喉頭全摘術を施行した。病理組織の結果は乳頭癌であった。また胸 骨にも腫瘤を認めたが PET-CT で集積なく、経過観察をしていたが、腫瘤径の増大、サイログロブリンの上昇あり CT ガ イド下に生検を行ったところ乳頭癌と診断され胸骨摘出術を行った。骨性胸壁の再建にメッシュを使用しその上に一部内側 で切断されている大胸筋を用い、周囲から剥離し正中で縫合し被覆した。術後、強い胸部痛が見られたが呼吸状態は安定し 術後10日で退院となる。本症例について、若干の文献的考察を加え報告する。

\section{0 気道狭窄のため心肺補助装置を用いながら挿管を行い手術した甲状腺悪性リンパ腫症例の検討}

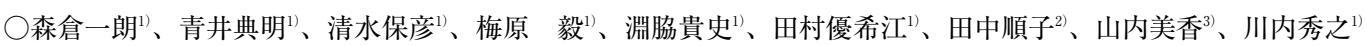
島根大学 医学部 耳鼻咽喉科 ${ }^{11}$ 、島根大学 医学部 血液内科 ${ }^{2)}$ 、島根大学 医学部 内分泌代謝内科 ${ }^{3)}$

甲状腺に発生する進行期の腫瘍性病変は、気道狭窄、蒠下障害などの合併症を引き起こし、全身麻酔のための挿管や局所 麻酔下での気管切開が困難な症例が存在する。われわれは前頸部腫瘤にて受診した慢性甲状腺炎に合併した甲状腺 B 細胞性 悪性リンパ腫の症例を経験した。症例は74歳の女性で頸部腫瘤を主訴に当院内分泌代謝内科を受診した。頸部単純 CT 検査 では甲状腺右葉に $42 \times 49 \times 49 \mathrm{~mm}$ 大の腫瘍性病変を認め、3D-CTにて腫瘤により気管は膜様部から前方に強く圧迫され前 後径が $4 \mathrm{~mm}$ であった。FNAによる細胞診で悪性リンパ腫の疑いであり血液内科で化学療法を検討していたが、気道狭窄が 顕著となり腫瘤摘出術を予定した。気管切開や経口挿管が困難となることが予想され、心肺補助装置を用いながら内径 $5.5 \mathrm{~mm}$ の挿管チューブを捚入し気道を確保した。腫瘤は気管内腔への浸潤はなく、摘出した。病理組織学的所見で最終診 断はびまん性大細胞型 $\mathrm{B}$ 細胞性リンパ腫となり、化学療法の施行予定である。慢性甲状腺炎合併悪性リンパ腫症例について も言及する。 


\title{
101 当科で手術を施行した甲状腺癌症例の検討
}

\author{
○坂東伸幸、後藤 孝 \\ 社会医療法人北斗 北斗病院 耳鼻咽喉科・頭頸部外科
}

2007年 4 月から 2011年11月までに当科で手術を施行した甲状腺癌101例を検討した。内訳は男性38例、女性63例、年齢の 中央值64歳（40-84歳）であった。どのようなことで腫瘍が明らかになったかについては頸動脈エコーで偶然発見されたも のが38例、甲状腺エコーで発見されたものが22例、嗄声や前頸部腫脹を含む自覚症状は15例、FDG-PET 13例、医師の触診 6 例、CT 6 例などであった。発見契機別に原発腫瘍の腫瘍長径の平均を比較すると甲状腺エコー $1.2 \mathrm{~cm} 、 \mathrm{PET} 1.4 \mathrm{~cm}$ 、頸 動脈エコー $1.5 \mathrm{~cm} 、 \mathrm{CT} 1.7 \mathrm{~cm}$ 、触診 $1.9 \mathrm{~cm}$ 、症状自覚 $3.2 \mathrm{~cm}$ であり、症状自覚は有意に腫瘍長径が大きかった。FDG-PET を施行していた30例において SUV 值と腫瘍径に有意な正の相関を認めた。穿刺吸引細胞診では正診率は76\%であった。病 理組織学的には乳頭癌 96 例、滤胞癌 4 例、扁平上皮癌 1 例であった。手術術式は葉峡部切除が76例、全摘が 25 例、D 1 郭清 86例、D2b 郭清14例などであった。予後は扁平上皮癌 1 例以外はすべて生存している。その他、臨床的検討を加えたので 報告する。

\section{2 甲状腺乳頭癌における術後再発の頻度とリスク因子の検討}

○植木雄司、今野昭義、間多祐輔

総合南東北病院

2002年 4 月〜2011年 3 月の期間に当科で治療を行った甲状腺乳頭癌新鮮例203例を対象とした。経過観察中 23 例で再発が みられた。このうち17例は頸部外側区リンパ節転移を、6例は遠隔転移をおこした。【1】初回手術時における腺外浸潤 （Ex 分類）の有無、【2】頸部外側区リンパ節転移の有無、【3】年齢の3 項目について再発率を比較した。【1】腺外浸潤 の有無：pEx0 3.1\%、pEx1 14.8\%、pEx2 26.7\% に頸部外側区リンパ節転移が出現し、pEx0 0.78\%、pEx2 33.3\%で遠隔 転移がみられた。腺外浸潤がみられる症例で再発率は高かった。【2】初回手術時に頸部外側区リンパ節転移がみられた群 では $36 \%$ が再発し、転移がみられなかった群では $6.9 \%$ が再発し、頸部外側区リンパ節転移群で再発率が高かった。【3】45 歳未満と 45 歳以上の症例での再発率をみると 45 歳未満では $9.8 \%$ 、45歳以上では $11.7 \%$ ときな差は認めなかった。自験例 に扔いて甲状腺乳頭癌の術後再発の頻度とリスク因子を検討した。

\section{3 隣接臓器浸潤を来した甲状腺癌の検討}

○下出祐造 ${ }^{1)}$ 、山本純平 ${ }^{11}$ 、宮澤 徹 $^{21} 、$ 辻 裕之 $^{11}$

金沢医科大学 耳鼻咽喉科・頭頸部外科学教室 ${ }^{11}$ 、浅八川総合病院 耳鼻咽喉科 ${ }^{2}$

甲状腺癌は未分化癌を除き一般に悪性度が低く、初回や再発でも長期予後が期待でき、たとえ担癌でも将来の合併症を考 慮した治療が必要となる。そのため反回神経、気管、喉頭、食道、総頸動脈などの隣接臓器へ浸潤を認めていても、治療効 果と術後の QOL を考慮した上で浸潤臓器を切除し機能再建手術を行う場合がある。今回、当科において隣接臓器浸潤を来 した未分化癌を除く甲状腺癌に対して浸潤臟器を含めた外科的治療を施行した症例を対象に、術後の局所制御率、生存率な ど検討を行った。

対象は2005年 4 月から 2011 年 3 月までの 7 年間に当科で手術加療を施行した甲状腺癌133例の内、隣接臟器へ浸潤を来し 合併切除（気管 shaving を除く）を施行した11例である。男性 5 例、女性 6 例で平均年齢は 63 歳、平均経過観察期間は 40.7 月である。浸潤臟器は気管 8 例、反回神経 4 例、喉頭 2 例、食道 2 例、総頸動脈 2 例（重複あり）であった。 3 年生 存率は $90.9 \%$ 、局所再発率は $9.1 \%$ あった。

\section{4 当科における甲状腺癌の喉頭・気管浸潤症例の検討}

○滝下照章、門田伸也、平田裕二、河野達也

四国がんセンター 頭頸科

甲状腺癌は一般的に予後良好だが、周囲臟器である喉頭・気管への浸潤は厳しい予後が推測される。喉頭・気管への浸潤 は、気道や燕下機能に直接影響し、生命予後を不良にするだけでなく、QOL低下にも関与するため、その制御と機能温存 が重要である。

2006年から2011年の 5 年間で、当院で手術を施行した甲状腺癌例のうち喉頭・気管浸潤症例38例で検討を行った。気管層 状切除は 28 例、気管全層切除は 5 例、喉頭全摘は 1 例、咽喉食摘は 1 例、喉頭部分切除は 3 例であった。

気管層状切除例のうち、低分化癌 1 例と乳頭癌 1 例で局所再発を認めた。気管全層切除例では局所再発はなかったが、未 分化癌 2 例が遠隔転移死した。喉頭全摘施行の 1 例も未分化癌で遠隔転移死したが、気道は保たれていた。

未分化癌では遠隔転移が多いことから、喉頭浸潤例では機能温存にこだわるよりも、十分な安全域を要する点や、確実に 気道確保を行い早期の退院を目指す観点からも、喉頭全摘を積極的に考えるが、一方で分化癌では喉頭温存と機能保持を念 頭においた、切除と再建の工夫が必要である。 